\title{
HUBUNGAN KEPADATAN SIPUT (Drupella) DENGAN KONDISI EKOSISTEM TERUMBU KARANG DI PERAIRAN PULAU SEMUJUR PROVINSI KEPULAUAN BANGKA BELITUNG
}

\author{
THE RELATIONSHIP BETWEEN DRUPELLA SNAIL DENSITY AND THE CONDITION OF THE CORAL REEF \\ ECOSYSTEM IN THE WATERS OF SEMUJUR ISLAND, PROVINCE OF BANGKA BELITUNG ISLANDS.
}

\author{
ISTIQOMAH $^{1}$, Okto Supratman ${ }^{2}$ dan Indra Ambalika Syari ${ }^{3}$ \\ Jurusan Manajemen Sumberdaya Perairan FPPB-UBB, Balunijuk \\ Program Studi Ilmu Kelautan, FPPB-UBB, Balunijuk
}

Email Korespodensi : istiqomahhebat@gmail.com

Diterima September; disetujui Oktober; tersedia secara online Oktober

\begin{abstract}
This research aims to analyse density of Drupella's on coral reef ecosystem, analyze the percentage of coral cover and analyze the relationship between the density of Drupella with environmental factors and conditions coral reef ecosystem in the waters of Semujur Island. Research data retrieval in April 2019 in the waters of Semujur Island. Drupella data retrieval using Belt Transect method and coral reef data retrieval using Line Intercept Transek. The results showed that the highest overall density of Drupella is in the area of coral, which is 244 ind/100m and the

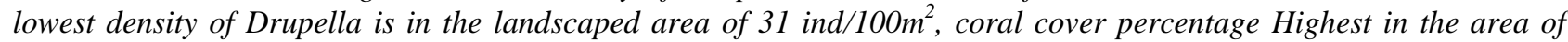
coral average of $72.20 \%$ and the lowest $23.44 \%$ while on the highest cover area of $54.96 \%$ and lows of $29.14 \%$. Principal Component Analysis (PCA) in the reef flats and Drupella watersheds correlates with temperature, current, pH, Dissolved Oxygen and Total Suspended Solid. Correspondence Analysis (CA) in the reef flats was found that Drupella was positively correlated with lifeforms acropora submassive, acropora tabulate, coral submassive, and coral massive. In the slope area of the Drupella positively correlated with the type of lifeform acropora digitate, acropora submassive, acropora tabulate, coral submassive, and coral branching.
\end{abstract}

Keywords: Drupella, Density, Coral Reef, Semujur Island.

PENDAHULUAN

Pulau Semujur termasuk wilayah di kecamatan Pangkalan Baru, Kabupaten Bangka Tengah dengan luas sebesar 40 ha (DKP, 2007). Pulau Semujur memiliki beragam biota laut yang berasosiasi dengan terumbu karang. Kondisi terumbu karang di perairan Pulau Semujur pada kedalaman 4-7 meter masih dalam keadaan baik meskipun dijumpai beberapa karang mati (DKP, 2007).

Banyak biota laut yang hidup dan berasosiasi dengan ekosistem terumbu karang baik menetap, berkembang biak maupun mencari makan. Ekosistem terumbu karang memiliki keragaman kehidupan laut yang tinggi. Setiap organisme yang ada dalam ekosistem ini memiliki peran penting dalam menjaga keseimbangan sistem yang kompleks. Keragaman tersebut menjadikan ekosistem terumbu karang mampu mendukung berbagai tingkat tropik kehidupan mulai dari produsen sampai predator. Beberapa predator aktif mengkonsumsi jaringan polip karang yaitu Drupella (ARBI, 2009).

Drupella merupakan salah satu jenis siput laut yang hidup di terumbu karang. Siput ini termasuk dalam filum Moluska, kelas Gastropoda, dan famili Muricidae yang dicirikan dengan cangkang tunggal yang berada pada bagian luar tubuh. Drupella hidup berkelompok menempel pada karang untuk mengkonsumsi jaringan polip karang dan meninggalkan bekas berwarna putih.
Drupella termasuk jenis siput pemakan karang yang penting untuk diketahui keberadaannya (LALANG ET AL. 2013). Drupella di terumbu karang sebagai pemangsa karang (ARBI, 2009). Terdapat 3 spesies Drupella yang teridentifikasi yaitu Drupella cornus, Drupella fragum dan Drupella rugosa (CUMMING, 1999).

Keberadaan Drupella merupakan salah satu masalah dalam pengelolaan kelestarian terumbu karang. Drupella merupakan pemangsa karang yang berbahaya apabila terjadi ledakan populasi (RISKA ET AL. 2013). Jika fenomena tersebut terjadi dalam waktu yang cukup lama dan dalam area yang luas maka akan terjadi kerusakan terumbu karang. Berdasarkan uraian tersebut, maka dilakukan penelitian untuk mengetahui dan mengkaji lebih lanjut mengenai keberadaan Drupella pada ekosistem terumbu karang di perairan Pulau Semujur.

Penelitian ini bertujuan untuk menganalisis kepadatan Drupella pada ekosistem terumbu karang, persentase tutupan karang sebagai habitat Drupella dan hubungan kepadatan Drupella dengan parameter perairan dan ekosistem terumbu karang di Perairan Pulau Semujur.

\section{METODELOGI}

Penelitian ini dilaksanakan pada bulan April 2019. Lokasi penelitian bertempat di Perairan Pulau Semujur Kepulauan Bangka Belitung. Peta lokasi penelitian ini disajikan pada Gambar 1. 


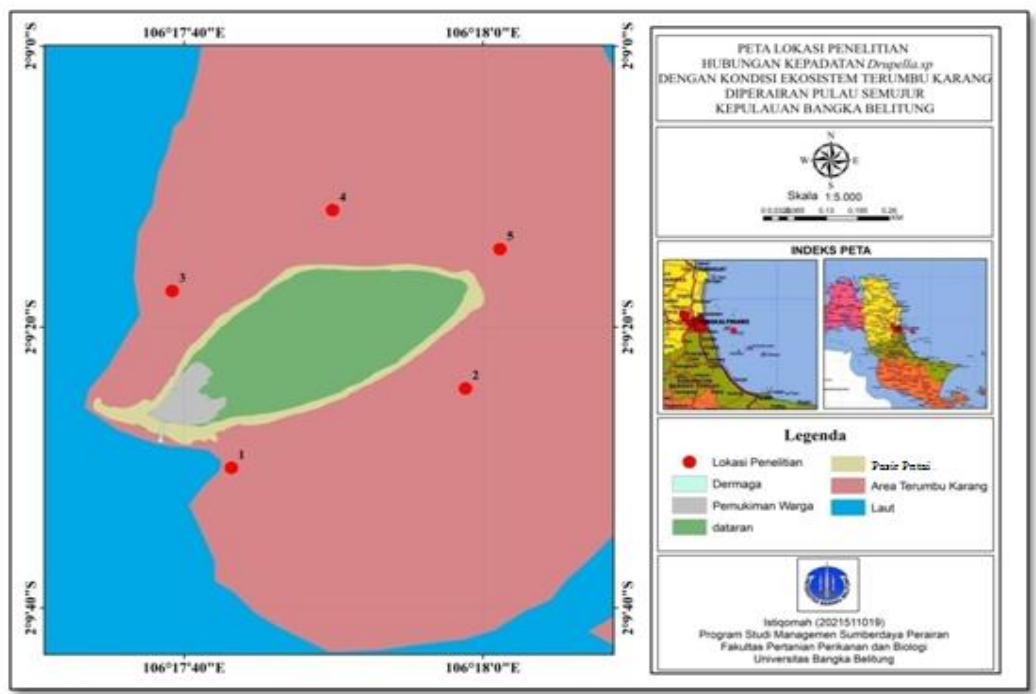

Gambar 1. Peta Lokasi Penelitian

Alat dan bahan yang akan digunakan dalam pengambilan data penelitian ini disajikan pada Tabel 1.

Tabel 1. Alat dan Bahan

\begin{tabular}{lll}
\hline No. & \multicolumn{1}{c}{ Alat dan Bahan } & \\
\hline 1. & Roll meter & Fungsi \\
2. & GPS & Menentukan panjang transek pengambilan data \\
3. & SCUBA & Mementukan titik stasiun pengamatan \\
4. & Alat Tulis Underwater & Alat bantu untuk pengambilan data \\
$\mathbf{5 .}$ & Plastik sampel & Mencatat hasil di lapangan \\
6. & Termometer & Tempat sampel Drupella yang ditemukan \\
7. & pH meter & Mengukur suhu perairan \\
$\mathbf{8 .}$ & Secchi disk & Mengukur pH perairan \\
9. & Salinity & Mengukur kedalaman dan kecerahan perairan \\
10. & Mistar/Jangka Sorong & Mengukur salinitas \\
11. & Stopwatch & Mengukur panjang dan lebar sampel \\
12. & DO meter & Mengukur kecepatan arus \\
13. & Kamera Underwater & Mengukur oksigen terlarut \\
14. & Botol sampel & Dokumentasi kegiatan \\
15. & Tongkat T & Wadah air untuk mengukur TSS dan DO \\
16. & Oven & Alat bantu pengambilan data \\
17. & Timbangan digital & Memanaskan residu (pengukuran TSS) \\
18. & Kertas Whatman & Menimbang kertas dan residu (pengukuran TSS) \\
19. & Indonesian Shells (Dharma, 1998) & Menyaring residu pada sample air (pengukuran TSS) \\
20. & Suharsono, 2008 dan Veron, 2000 & Buku Identifikasi Gastopoda (Drupella) \\
& & Buku Identifikasi (lifeform) terumbu karang \\
\hline
\end{tabular}

Penentuan lokasi penelitian ini dilakukan dengan beberapa pertimbangan tertentu oleh peneliti (FACHRUL, 2007). Penentuan titik sampling dilakukan berdasarkan pertimbangan dengan memperhatikan daerah keterwakilan terumbu karang di perairan Pulau Semujur.

.Tabel 2. Titik Pengambilan Data

\begin{tabular}{|c|c|c|}
\hline Stasiun & Koordinat & Karakteristik Lokasi \\
\hline 1 & $\begin{array}{l}2^{\circ} 09^{\prime} 37.0^{\prime \prime} \text { LS dan } \\
106^{\circ} 17^{\prime} 42.3^{\prime \prime} \mathrm{BT}\end{array}$ & $\begin{array}{l}\text { Daerah yang dekat dengan dermaga, tempat bersandarnya kapal untuk penyeberangan, } \\
\text { berhadapan dengan Pulau Bangka. }\end{array}$ \\
\hline 2 & $\begin{array}{l}2^{\circ} 09^{\prime} 31.7^{\prime \prime} \text { LS dan } \\
106^{\circ} 18^{\prime} 09.9^{\prime \prime} \mathrm{BT}\end{array}$ & Daerah semi terbuka karena terdapat hamparan terumbu karang yang cukup luas. \\
\hline 3 & $2^{\circ} 09^{\prime} 07.3$ " LS dan & \\
\hline 4 & $\begin{array}{l}106^{\circ} 17^{\prime} 37.9^{\prime \prime} \text { BT } \\
2^{\circ} 08^{\prime} 44.3^{\prime \prime} \text { LS dan }\end{array}$ & Daerah perairan dengan hamparan karang yang menghadap ke daerah laut terbuka. \\
\hline 5 & $\begin{array}{l}106^{\circ} 17^{\prime} 53.6^{\prime \prime} \mathrm{BT} \\
2^{\circ} 09^{\prime} 05.4^{\prime \prime} \mathrm{LS} \text { dan }\end{array}$ & Daerah perairan dengan hamparan karang yang menghadap ke daerah laut terbuka. \\
\hline
\end{tabular}

Pengambilan data Drupella menggunakan metode Belt Transect dilakukan dengan cara membentangkan line transect sepanjang 50 meter dengan jarak 1 meter ke
Lokasi pengambilan data dilakukan pada 5 stasiun berdasarkan keterwakilan terumbu karang Pulau Semujur (Gambar 1). Setiap stasiun pengamatan dilakukan 2 kali pengulangan yaitu pada daerah rataan (flate) karang dan tubir (slope). Keterangan singkat stasiun penelitian dapat dilihat pada Tabel 2

kanan dan 1 meter ke kiri. Metode ini digunakan untuk mengamati Drupella dengan melihat dan menghitung jumlah dari biota tersebut (HILL AND WILKINSON, 2004). Pengamatan Drupella dilakukan dengan cara 
visual sensus berupa dokumentasi dan koleksi beberapa sampel Drupella yang terdapat di dalam transek pengamatan. Pengambilan data Drupella di ekosistem terumbu karang dilakukan mengarah sejajar garis pantai. Penggunaan metode Belt Transek telah dilakukan di beberapa penelitian sebelumnya yang berkaitan dengan kepadatan ataupun kelimpahan Drupella di terumbu karang seperti yang dilakukan LALANG ET AL. 2013;RISKA ET AL. 2013. Ilustrasi pengambilan data dapat dilihat pada Gambar 3.

$\mathrm{Pe}$

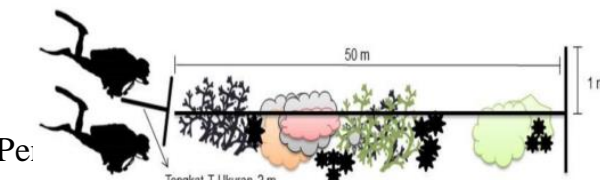

ilakukan

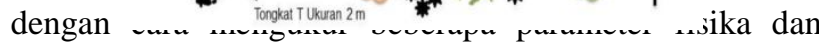

kimia perairan diantaranya:

\begin{tabular}{lll}
\hline No. & Parameter & Alat Pengukuran \\
\hline 1. & Suhu & thermometer \\
2. & pH (Potential Hydrogen) & pH paper \\
3. & Salinitas & salinity \\
4. & Kecepatan Arus & bola arus dan stopwatch \\
5. & DO (Dissolved Oxygen) & DO meter \\
6. & Kecerahan & secchi disc \\
7. & TSS ( Total Suspended & kertas Whatman \\
\hline
\end{tabular}

Analisis Data

Kepadatan Drupella

Kepadatan Drupella dapat dihitung dengan rumus (BROWER ET AL. 1998):

$$
\mathrm{D}_{1}=\underline{n 1}
$$

Keterangan :

$\mathrm{D}_{1} \quad$ = Kepadatan individu spesies ke-i

$\mathrm{n}_{1} \quad=$ Jumlah individu dari spesies ke-i

$\mathrm{A}=$ Luas plot pengambilan contoh $\left(100 \mathrm{~m}^{2}\right)$ dikonversikan ke hektar (ha)

Persentase Tutupan Terumbu Karang

Nilai persentase penutupan terumbu karang diperoleh dari hasil pengukuran lifeform karang dengan menggunakan rumus (ENGLISH ET AL. 1994) :

$$
L=\frac{L i}{N} \mathrm{X} 100 \%
$$

Keterangan :

$\mathrm{L} \quad=$ Persentase penutupan karang (\%)

$\mathrm{Li}=$ Panjang lifeform (intercept koloni) jenis kategori ke-i

$\mathrm{N}=$ Panjang transek $\left(100 \mathrm{~m}^{2}\right)$

Kriteria kondisi terumbu karang berdasarkan persentase penutupan karang hidup menurut KepMen LH No. 4 Tahun 2001 tentang Baku Mutu Kerusakan Terumbu Karang disajikan pada Tabel 3.

Tabel 3. Kriteria Penilaian
Gambar 3. Ilustrasi pengambilan data Drupella

Pengambilan data terumbu karang dilakukan dengan menggunakan metode Line Intersept Transect (LIT) dengan cara membentangkan line transect sepanjang 50 meter searahkan sejajar garis pantai. Metode ini dilakukan bertujuan untuk memantau dan mengamati tutupan terumbu karang (HILL AND WILKINSON, 2004). Pengamatan terumbu karang dilakukan dengan cara visual sensus yaitu berupa dokumentasi dengan menggunakan video yang kemudian akan diidentifikasi sampai tingkat lifeform (SUHARSONO, 2008; VERON, 2000).

\begin{tabular}{ccc}
\hline No. & Persentase Tutupan Karang(\%) & Kreteria \\
\hline 1. & $0-24,9$ & Rusak \\
2. & $25,0-49,0$ & Sedang \\
3. & $50,0-74,9$ & Baik \\
4. & $75,0-100,0$ & Baik Sekali \\
\hline
\end{tabular}

Hubungan kepadatan Drupella dengan Parameter Perairan Analisis Principal Component Analysis (PCA). Metode analisis tersebut dilakukan menggunakan aplikasi Statistica 6.0. Analisis ini menggunakan metode deskriptif yang bertujuan untuk mempresentasikan informasi maksimum yang terdapat pada suatu matriks data dalam bentuk grafik. Matrik data yang digunakan terdiri atas stasiun penelitian sebagai (baris matriks data) serta data parameter lingkungan dan beberapa kategori penutupan terumbu karang dan bentuk pertumbuhan sebagai variable statistik (kolom matriks data) (BENGEN, 2000).

Hubungan kepadatan Drupella dengan Terumbu Karang

Analisis Correspondence Analysis (CA), menggunakan aplikasi Statistica 6.0. Correspondence Analysis merupakan salah satu bentuk analisis statistik multivariabel. Analisis ini didasarkan pada matriks data (baris) berupa stasiun pengamatan dengan kolom berupa nilai kepadatan Drupella dan bentuk pertumbuhan karang dengan persentase tutupan karang. Matriks data merupakan tabel korelasi persentase dan bentuk pertumbuhan karang $\mathrm{x}$ kepadatan Drupella berikut (BENGEN, 2000).

\section{HASIL DAN PEMBAHASAN \\ Hasil \\ Kepadatan Drupella}

Kepadatan merupakan jumlah individu suatu spesies dibagi luas area pengamatan (BROWER ET AL. 1998). Terdapat 2 spesies Drupella yang ditemukan di Pulau Semujur yaitu Drupella rugosa dan Drupella cornus. Nilai kepadatan keseluruhan Drupella tertinggi di Pulau Semujur terdapat pada daerah rataan karang sebanyak 84 ind $/ 100 \mathrm{~m}^{2}$ dan kepadatan Drupella terendah terdapat pada daerah tubir sebanyak 0 ind $/ 100 \mathrm{~m}^{2}$ (tidak ditemukan). Kepadatan Drupella di Pulau Semujur dapat dilihat pada Tabel 4. 
Tabel 4. Kepadatan Drupella (individu/ha) di setiap stasiun

\begin{tabular}{|c|c|c|c|c|c|c|c|c|c|c|c|c|}
\hline \multicolumn{13}{|c|}{ Stasiun } \\
\hline \multirow[t]{2}{*}{ Spesies } & \multicolumn{2}{|r|}{1} & \multicolumn{2}{|c|}{2} & \multicolumn{2}{|c|}{3} & \multicolumn{2}{|c|}{4} & \multicolumn{2}{|c|}{5} & \multirow[t]{2}{*}{ Slope } & \multirow[t]{2}{*}{ Flate } \\
\hline & S & $\mathrm{F}$ & $S$ & F & S & $\mathrm{F}$ & S & $\mathrm{F}$ & S & $\mathrm{F}$ & & \\
\hline Drupella rugosa & 0 & 3.300 & 800 & 25.00 & 500 & 1.900 & 800 & 6.500 & 700 & 7.900 & 2.800 & 22.100 \\
\hline Drupella cornus & 0 & 800 & 200 & 300 & 0 & 200 & 0 & 500 & 100 & 500 & 300 & 2.300 \\
\hline$\sum$ individu /ha & 0 & 4.100 & 1.000 & 2.800 & 500 & 2.100 & 800 & 7.000 & 800 & 8.400 & 3.100 & 24.400 \\
\hline
\end{tabular}

Keterangan : (S) Slope (tubir) dan (F) Flate (rataan karang)

\section{Persentase Tutupan Terumbu Karang}

Berdasarkan hasil pengamatan yang telah dilakukan, ditemukan 10 jenis lifeform (bentuk pertumbuhan), algae, dead coral (karang mati), abiotic (abiotik) dan others

Tabel 5. Persentase tutupan terumbu karang (\%) di setiap stasiun fauna (biota lain) di lokasi pengamatan. Persentase tutupan terumbu karang Pulau Semujur disajikan pada Tabel 5.

\begin{tabular}{|c|c|c|c|c|c|c|c|c|c|c|}
\hline \multicolumn{11}{|c|}{ Stasiun } \\
\hline \multirow{2}{*}{ Lifeform } & \multicolumn{2}{|c|}{1} & \multicolumn{2}{|c|}{2} & \multicolumn{2}{|c|}{3} & \multicolumn{2}{|c|}{4} & \multicolumn{2}{|c|}{5} \\
\hline & $\mathrm{F}$ & $\mathrm{S}$ & F & $S$ & $\mathrm{~F}$ & $\mathrm{~S}$ & $\mathrm{~F}$ & $\mathrm{~S}$ & $\mathrm{~F}$ & $\mathrm{~S}$ \\
\hline$A C B$ & 2,84 & 3,76 & 0 & 1,36 & 17,22 & 1,66 & 0 & 0,8 & 0 & 0,32 \\
\hline$A C D$ & 14,34 & 5,2 & 0 & 0 & 14,2 & 0 & 0 & 0 & 0 & 0 \\
\hline$A C T$ & 6,04 & 5,82 & 0 & 2,74 & 18,9 & 0 & 0 & 0 & 2,42 & 1,94 \\
\hline$A C S$ & 1,1 & 7,94 & 6,66 & 4,2 & 0 & 0 & 13,72 & 0 & 0,76 & 7,64 \\
\hline$C B$ & 0 & 5,5 & 0 & 0 & 0 & 1,5 & 0 & 0,6 & 0 & 2,24 \\
\hline$C E$ & 4,6 & 2,66 & 0,3 & 0,46 & 5,78 & 8,7 & 0 & 2,98 & 2,96 & 0,3 \\
\hline$C F$ & 19,26 & 8,1 & 9,2 & 9,64 & 13,22 & 28,56 & 5,98 & 10,48 & 2,98 & 13,14 \\
\hline$C M$ & 5,46 & 6,62 & 4,66 & 0,8 & 1,22 & 6,3 & 15,4 & 6,86 & 11,76 & 3,9 \\
\hline$C S$ & 3,76 & 1 & 7,62 & 4,24 & 1,66 & 2,44 & 2,54 & 6,32 & 2,24 & 3,6 \\
\hline$C M R$ & 0 & 1,4 & 0,7 & 0 & 0 & 5,8 & 0,84 & 2,42 & 1,78 & 2,62 \\
\hline$O T$ & 4,88 & 0,2 & 1,96 & 1,88 & 1,22 & 1,86 & 0,4 & 2,98 & 3,06 & 2,02 \\
\hline$S C$ & 1,06 & 0,2 & 0,24 & 0 & 0 & 0 & 2,6 & 0 & 0,96 & 0 \\
\hline$D C$ & 7,76 & 0,9 & 0 & 0,4 & 0,32 & 4,68 & 0,2 & 0,76 & 3,02 & 0,96 \\
\hline$D C A$ & 14,88 & 48,9 & 43,2 & 53,14 & 9,96 & 34,2 & 43,46 & 55,58 & 37,96 & 28,8 \\
\hline Rubble & 0,8 & 0 & 1,3 & 0,86 & 0,64 & 0 & 2,6 & 0 & 1,88 & 0,6 \\
\hline$M A$ & 0,5 & 0 & 9,06 & 0,14 & 7,24 & 0 & 3,48 & 0 & 19.98 & 2,84 \\
\hline$T A$ & 1,82 & 0 & 1,92 & 0,8 & 0 & 0 & 2,4 & 0 & 4,2 & 4,38 \\
\hline Sand & 1 & 1,8 & 2,96 & 0 & 0 & 1,92 & 0,1 & 5.34 & 0 & 0 \\
\hline Silt & 0,3 & 0 & 4,64 & 16,34 & 1 & 2,38 & 0,6 & 4,88 & 0,42 & 11,76 \\
\hline Water & 5,96 & 0,2 & 5,58 & 2,06 & 3,74 & 0 & 5,58 & 0 & 3,12 & 12,1 \\
\hline Rock & 3,64 & 0 & 0 & 0,94 & 3,68 & 0 & 0 & 0 & 0,5 & 0,84 \\
\hline Jumlah & 100 & 100 & 100 & 100 & 100 & 100 & 100 & 100 & 100 & 100 \\
\hline
\end{tabular}

Keterangan : Stasiun $=(\mathbf{S})$ Slope (tubir) dan $(\mathbf{F})$ Flate (rataan karang) ACB (Acropora Branching), ACD (Acropora Digitate), ACT (Acropora Tabulate), ACS (Acropora Submassive), CB (Coral Branching), CE (Coral Encrusting), CF (Coral Foliose), CM (Coral Massive), CS (Coral Submassive), CMR (Coral Mushroom), OT (Others), SC (Soft Coral), DC (Dead Coral), DCA (Dead Coral Algae), Rubble, MA (Macroalgae), TA (Turf Algae), Sand (Pasir), Silt (Lumpur), Water (Air), dan Rock (Batu).

Hasil analisis data berupa persentase tutupan karang hidup dan kondisi ekosistem terumbu karang berdasarkan Kepmen LH No.4 Tahun 2001 tentang Baku Mutu Kriteria Kerusakan Terumbu Karang disajikan pada Tabel 6. Nilai persentase tertinggi pada daerah tubir terdapat pada stasiun 3 dengan nilai persentase tutupan

Tabel 6. Persentase dan Kriteria Tutupan Karang Hidup

\begin{tabular}{cccc}
\hline Stasiun & & Tutupan $(\%)$ & Kategori \\
\hline 1 & F & 57,40 & Sedang \\
& S & 47,80 & Sedang \\
2 & F & 23,44 & Rusak \\
& S & 35,70 & Sedang \\
3 & F & 72,20 & Baik \\
& S & 54,96 & Baik \\
4 & F & 38,48 & Sedang \\
& S & 30,46 & Sedang \\
5 & F & 24,90 & Rusak \\
& S & 29,14 & Sedang \\
\hline
\end{tabular}

Keterangan : (F) Flate (Rataan Karang) dan (S) Slope(Tubir) karang hidup sebesar 54,96\% dan nilai terendah terdapat pada stasiun 5 sebesar $29,14 \%$. Sedangkan pada daerah rataan karang nilai persentase tutupan karang hidup tertinggi terdapat pada stasiun 3 sebesar $72,20 \%$ dan nilai persentase terendah terdapat pada stasiun 2 sebesar $23,44 \%$.

\section{Parameter Kualitas Perairan}

Data kualitas perairan merupakan parameter fisikakimia yang menjadi faktor pembatas kehidupan biota Drupella meliputi suhu, $p H$, salinitas, Dissolved Oxygen, kecerahan, kecepatan arus dan Total Suspended Solid disajikan pada Tabel 7. Nilai parameter fisika-kimia perairan perairan Pulau Semujur secara keseluruhan tidak mengalami perbedaan yang terlalu signifikan. Nilai Suhu pada stasiun pengamatan berkisar $29-31{ }^{\circ} \mathrm{C}, \mathrm{pH}$ berkisar 
7,1-7,3, Salinitas berkisar 31-33\%o, Dissolved Oxygen berkisar 4,23-4,77, Kecerahan berkisar 96-100\%,
Kecepatan arus berkisar $0,07-0,11 \mathrm{~m} / \mathrm{s}$ dan Total Suspended Solid berkisar 0,12-0,20 mg/L.

Tabel 7. Parameter kualitas perairan

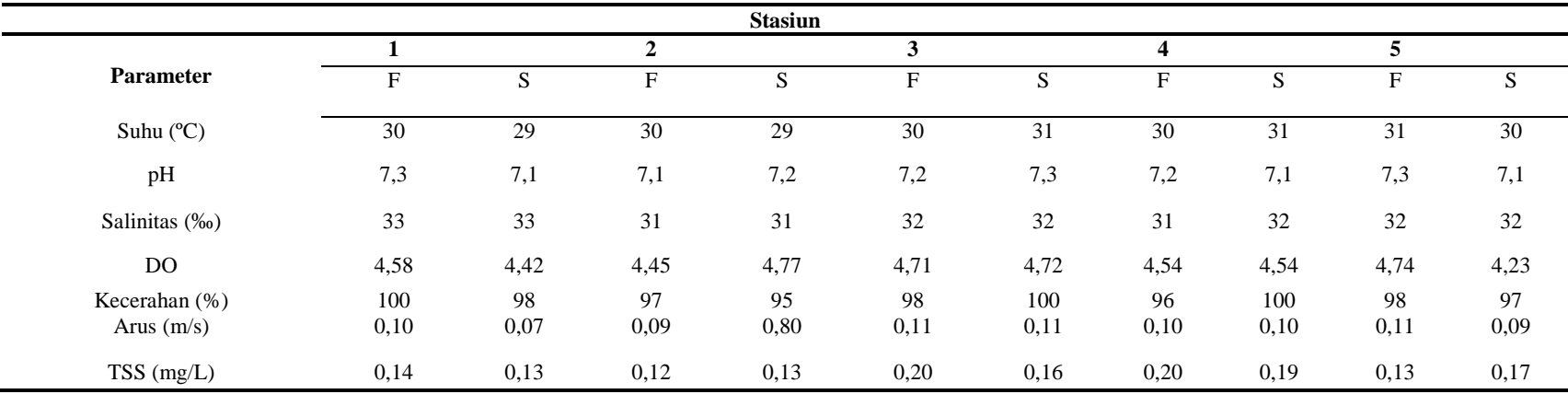

Hubungan Kepadatan Drupella dengan Parameter Perairan pada daerah rataan karang dan tubir

Nilai kepadatan Drupella dan parameter perairan di lokasi pengamatan daerah rataan karang disajikan sumbu F1 dan F2 masing-masing bernilai 62,29\% dan 25,62\%, sehingga diperoleh nilai total sebesar $87,91 \%$. Drupella rugosa dan Drupella cornus berkorelasi positif dengan parameter suhu, arus, $\mathrm{pH}$, Dissolved Oxygen dan Total Suspended Solid disajikan pada Gambar 5. (a)
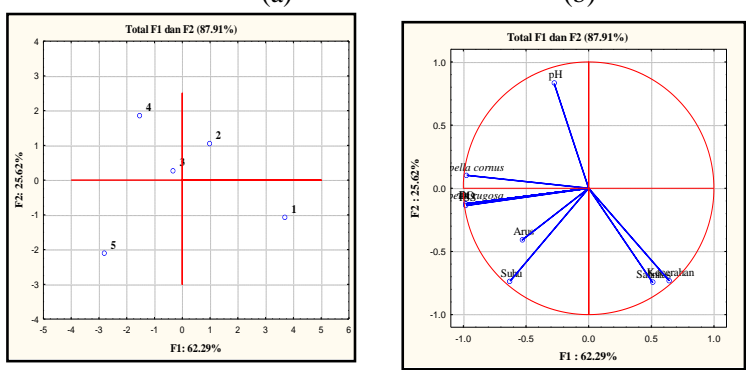

Keterangan : Kepadatan Drupella rugosa, Drupella cornus dan parameter lingkungan (suhu, $\mathrm{pH}$,salinitas, DO, kecerahan, arus dan TSS).

Gambar 5. Analisis Komponen Utama kepadatan Drupella dengan parameter perairan daerah rataan karang: (a) Lingkaran korelasi antar parameter perairan; (b) Penyebaran stasiun

Nilai kepadatan Drupella dan parameter perairan di lokasi pengamatan daerah tubir disajikan sumbu F1 dan F2 masingmasing bernilai $51,59 \%$ dan $27,95 \%$, sehingga diperoleh nilai total sebesar 79,54\%. Drupella rugosa berkorelasi positif dengan parameter Dissolved Oxygen, arus, Total Suspended Solid, suhu dan pH. Drupella cornus berkorelasi positif dengan parameter Dissolved Oxygen, arus dan Total Suspended Solid disajikan pada Gambar 6.

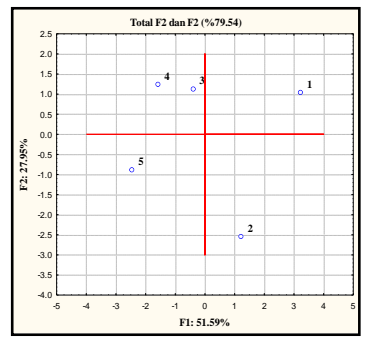

(a)

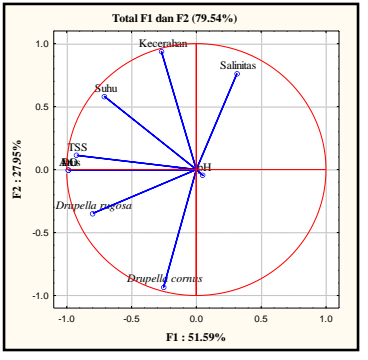

(b)
Keterangan : Kepadatan Drupella rugosa, Drupella cornus dan parameter lingkungan (suhu, $p H$,salinitas, $D O$, kecerahan, arus dan TSS).

Gambar 6. Analisis Komponen Utama kepadatan Drupella dengan parameter perairan daerah tubir: (a) Lingkaran korelasi antar parameter perairan ; (b) Penyebaran stasiun

\section{Hubungan kepadatan Drupella dengan Persentase Tutupan karang daerah rataan karang dan tubir}

Hasil Correspondence Analysis (CA) menunjukkan hubungan Drupella dengan lifeform karang di 5 stasiun pengamatan daerah rataan karang sumbu utama F1 dan F2 masing-masing bernilai $58,71 \%$ dan $28,24 \%$ sehingga nilai total sebesar $86,95 \%$. Drupella berkorelasi positif dengan acropora submassive dan acropora tabulate, coral submassive dan coral massive disajikan pada Gambar 7.

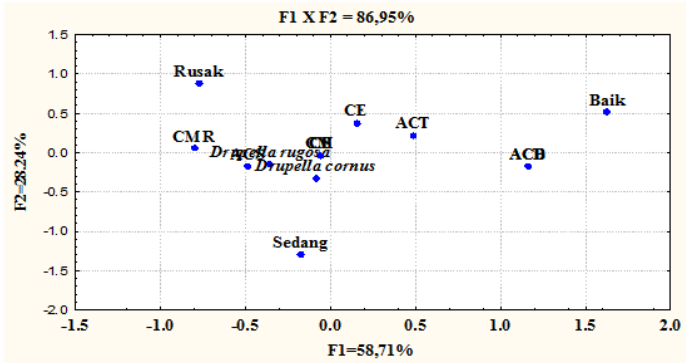

Keterangan : ACB (Acropora Branching), ACD (Acropora Digitate), ACT (Acropora Tabulate), ACS (Acropora Submassive), CB (Coral Branching), CE (Coral 
Encrusting), CF (Coral Foliose), CM (Coral Massive), CS (Coral Submassive), CMR (Coral Mushroom).

Gambar 7. Correspondence Analysis (CA) hubungan kepadatan Drupella dengan terumbu karang pada daerah rataan karang.

Hasil Correspondence Analysis (CA) menunjukan hubungan Drupella dengan lifeform karang di 5 stasiun pengamatan daerah tubir pada sumbu utama F1 dan F2 masing-masing bernilai 49,86\% dan 23,88\% sehingga nilai total sebesar $73,74 \%$. Drupella rugosa berkorelasi positif dengan acropora digitate, acropora submassive, acropora tabulate dan coral submassive dan coral branching yang disajikan pada Gambar 8.

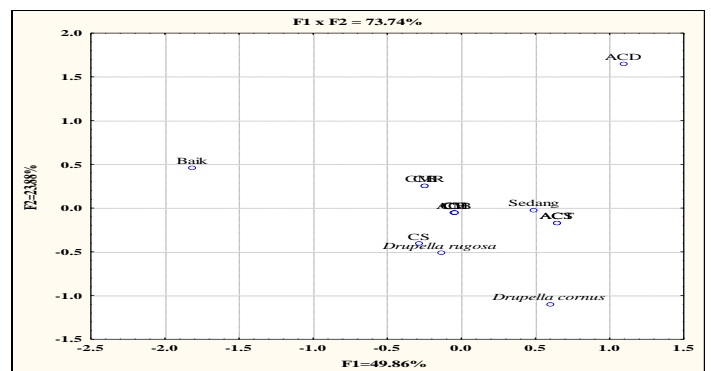

Keterangan : ACB (Acropora Branching), ACD (Acropora Digitate), ACT (Acropora Tabulate), ACS (Acropora Submassive), CB (Coral Branching), CE (Coral Encrusting), CF (Coral Foliose), CM (Coral Massive), CS (Coral Submassive), CMR (Coral Mushroom).

Gambar 8. Correspondence Analysis (CA) hubungan kepadatan Drupella dengan terumbu karang pada daerah tubir.

\section{Pembahasan \\ Kepadatan Drupella}

Drupella yang ditemukan di perairan Pulau Semujur terdiri dari 2 spesies yaitu Drupella rugosa dan Drupella cornus. Pulau Semujur memiliki keanekaragaman terumbu karang yang tinggi sehingga mendukung keberadaan Drupella untuk hidup dan memakan polip karang yang ada di pulau ini. Kepadatan Drupella pada setiap stasiun pengamatan sangat beragam baik pada daerah rataan karang maupun pada daerah tubir (Tabel 4).

Kepadatan Drupella tertinggi pada daerah rataan karang sebanyak 8.400 ind/ha terdapat pada stasiun 5 dikarenakan pada stasiun tersebut kondisi terumbu karang berada dalam kategori rusak terlihat dari beberapa bagian terumbu karang yang mengalami kerusakan akibat pemangsaannya. Pada daerah rataan karang didominasi oleh jenis coral massive dan acropora tabulate. Umumnya Drupella banyak ditemukan pada karang tersebut (LALANG ET AL. 2013). Sedangkan kepadatan Drupella terendah terdapat pada stasiun 3 sebanyak 2.100 ind/ha dikarenakan pada stasiun tersebut kondisi terumbu karang berada dalam kategori baik sehingga mengakibatkan Drupella cenderung untuk menghindari kontak langsung dengan sel penyengat karang (CUMMING, 1997).

Kepadatan Drupella tertinggi pada daerah tubir sebanyak 1.000 ind/ha pada stasiun 2 dikarenakan pada stasiun tersebut kondisi terumbu karang berada dalam kategori sedang dan jenis bentuk pertumbuhan karang didominasi oleh jenis coral foliose. Sedangkan kepadatan terendah terdapat pada stasiun 1 sebesar 0 ind/ha.

Tingginya jumlah kepadatan yang ditemukan tentunya tidak terlepas dari bentuk pertumbuhan bentuk pertumbuhan karang Acropora. Keberadaan Drupella pada suatu koloni karang tergantung pada pemilihan makan dan kondisi karang seperti aksesibilitas jaringan, nilai gizi, produksi lendir, dan penyengat karang (MORTON AND BLACKMORE, 2009).

Perbedaan nilai kepadatan yang diperoleh dari lokasi pengamatan yaitu pada daerah rataan karang dan tubir dipengaruhi faktor ekologis dan pemangsaan Drupella itu sendiri. Kehadiran suatu organisme sangat tergantung pada keadaan ekosistem atau lingkungan ekologi yang ada (LATUCONSINA, 2016). Faktor yang berpengaruh terhadap ada tidaknya Drupella pada suatu daerah adalah ketersediaan makanan dan cara pemilihan makan oleh individu itu sendiri (MORTON AND BLACKMORE, 2009).Kondisi karang seperti aksesibilitas jaringan, nilai gizi, produksi lendir, dan pertahan sel penyegat karang sangat menentukan posisi Drupella pada cabang karang (MORTON AND BLACKMORE, 2009).Drupella lebih banyak ditemukan pada daerah rataan karang dikarenakan bentuk pertumbuhan karang bercabang yang lebih mendominasi pada daerah rataan karang yang tentunya akan mampu penyokong kehidupan Drupella dan juga dikarenakan oleh faktor lingkungan dan ketersediaan makanan berupa polip karang pada karang bercabang lebih banyak dibandingkan dengan bentuk pertumbuhan lainnya serta sebagai tempat yang aman dari perburuan predator.

\section{Persentase Tutupan Terumbu Karang}

Perairan Pulau Semujur memiliki tipe terumbu karang tepi tumbuh mengelilingi pantai. Terumbu karang tumbuh pada daerah-daerah yang landai dan datar sampai pada tubir ke arah yang lebih dalam. Terumbu karang pada setiap stasiun pengamatan memiliki bentuk pertumbuhan karang yang beragam.

Persentase tutupan karang tertinggi pada daerah rataan karang terdapat pada stasiun 3 dengan nilai sebesar $72,20 \%$ termasuk dalam kategori baik. Sedangkan persentase tutupan terendah terdapat pada stasiun 2 dengan nilai sebesar $23,44 \%$ termasuk dalam kategori rusak.

Persentase tutupan karang tertinggi pada daerah tubir terdapat pada stasiun 3 dengan nilai sebesar 54,96\% termasuk dalam kategori baik. Sedangkan persentase tutupan terendah terdapat pada stasiun 5 dengan nilai sebesar 29,14\% termasuk dalam kategori sedang.

Persentase rata-rata tutupan terumbu karang hidup pada daerah rataan karang sebesar $43,28 \%$ lebih tinggi dibandingkan dengan daerah tubir sebesar 39,61\%. Keberadaan dan kepadatan makrobenthos seperti Drupella berkaitan erat dengan kondisi terumbu karang, dimana tingkat kesehatan terumbu karang juga ditentukan oleh berkurang atau bertambahnya biota yang hidup berasosiasi di habitat tersebut (Muzaki et al. 2010). 
Parameter lingkungan juga dapat berpengaruh terhadap kelangsungan hidup dan perkembangan terumbu karang.

\section{Parameter Kualitas Perairan}

Parameter perairan yang didapatkan dari hasil pengamatan yang telah dilakukan dengan beberapa parameter yang dijadikan sebagai indikator perairan yaitu pada daerah rataan karang maupun daerah tubir. Hasil pengukuran suhu di 5 stasiun pengamatan daerah rataan karang memiliki nilai berkisar antara $30-31{ }^{\circ} \mathrm{C}$ sedangkan pada daerah tubir memiliki nilai berkisar antara $29-31{ }^{\circ} \mathrm{C}$. Nilai tersebut masih berada dalam kategori baik dikarenakan kisaran suhu yang optimal bagi Drupella adalah $28-30{ }^{\circ} \mathrm{C}$ (MOYER ET AL. 1982).

Nilai $\mathrm{pH}$ yang diperoleh pada daerah rataan karang memiliki nilai berkisar antara 7,1-7,3 sedangkan pada daerah tubir memiliki nilai berkisar antara 7,1-7,3. Drupella dapat beradaptasi dan bertahan hidup dengan perubahan $\mathrm{pH}$ lingkungan perairan hingga nilai 7,5.

Nilai salinitas yang diperoleh pada daerah rataan karang memiliki nilai berkisar antara 31-33\% sedangkan pada daerah tubir memiliki nilai berkisar antara 31-33\%o. Kisaran normal salinitas perairan laut untuk perkembangan dan pertumbuhan terumbu karang secara optimal adalah 30-33 \% (Sadarun et al. 2008. Pada salinitas dibawah minimum dan maksimum terkadang hewan karang masih dapat hidup (SADARUN ET AL. 2008). Drupella dapat bertahan hidup dan berkembang biak dengan kisaran nilai salinitas 30-32\%o (Lalang et al. 2013).

Nilai Dissolved Oxygen atau oksigen terlarut yang diperoleh pada daerah rataan karang memiliki nilai berkisar antara 4,45-4,74 sedangkan pada daerah tubir memiliki nilai berkisar antara 4,23-4,77. Berkurangnya oksigen pada perairan tentunya akan berpengaruh terhadap kehidupan dan kelangsungan hidup biota yang hidup di dalamnya.

Nilai kecerahan yang diperoleh pada daerah rataan karang memiliki nilai berkisar antara 96-100\% sedangkan kecerahan pada daerah tubir memiliki nilai berkisar antara 95-100\%. Kecerahan perairan berhubungan dengan berapa besar penetrasi cahaya matahari yang masuk ke dalam perairan, karena dapat membantu karang untuk dapat tumbuh dengan baik (Lalang et al. 2013). Kecerahan di lokasi penelitian cukup tinggi karena penetrasi cahaya yang masuk ke dalam perairan pada beberapa stasiun dapat menembus sampai ke dasar perairan.

Kecepatan arus daerah rataan karang memiliki nilai berkisar antara 0,09-0,11 m/s sedangkan pada daerah tubir memiliki nilai berkisar antara $0,07-0,11 \mathrm{~m} / \mathrm{s}$. Nilai tersebut dapat berpengaruh terhadap pertumbuhan karang maupun kehidupan Drupella karena membawa sedimentasi dan partikel-partikel pasir di daerah tersebut dapat menghambat pertumbuhan dan pergerakan biota. Arus diperlukan untuk membersihkan endapan-endapan dan mensuplai oksigen dari laut bebas (LALANG ET AL. 2013).
Nilai Total Suspended Solid yang diperoleh pada daerah rataan karang memiliki nilai berkisar antara 0,12$0,20 \mathrm{~m} / \mathrm{L}$ sedangkan pada daerah tubir memiliki nilai berkisar antara $0,13-0,17 \mathrm{~m} / \mathrm{L}$. Nilai dari beberapa parameter perairan tersebut secara keluruhan masih berada dalam kategori baik dan masih mendukung pertumbuhan karang maupun keberadaan Drupella.

\section{Hubungan Kepadatan Drupella dengan Parameter Perairan pada daerah rataan karang dan tubir}

Grafik Principal Component Analysis (PCA) menunjukkan hubungan kepadatan Drupella dengan parameter lingkungan terlihat pada Gambar 5 (a). Hasil analisis menunjukkan kualitas informasi disajikan oleh kedua sumbu (F1 dan F2) dengan nilai total kepadatan Drupella pada setiap stasiun daerah rataan karang sebesar $87,91 \%$. Tabel faktor coordinate of the variables, factor coordinate of cases dan matrix correlation disajikan pada Lampiran 3.

Hubungan kepadatan Drupella dan parameter perairan menunjukkan bahwa Drupella berkorelasi positif dengan parameter suhu, arus, $\mathrm{pH}$, Dissolved Oxygen dan Total Suspended Solid. Korelasi tersebut menunjukkan adanya hubungan erat antara kepadatan Drupella dengan beberapa parameter perairan dikarenakan parameter tersebut memiliki pengaruh yang cukup besar terhadap keberadaan Drupella di Pulau Semujur.

Suhu perairan merupakan faktor yang dapat mempengaruhi keberadaan Drupella. Pada stasiun pengamatan daerah rataan karang memiliki rata-rata suhu sebesar $30-31{ }^{\circ} \mathrm{C}$. Tingginya suhu pada daerah rataan karang dibandingkan dengan daerah tubir dikarenakan adanya perbedaan intensitas cahaya yang masuk kedalam perairan dan juga perbedaan kedalaman perairan. Pada daerah rataan karang memiliki kedalaman 3-7 meter sehingga intensitas cahaya yang masuk akan lebih banyak sehingga kondisi perairan cenderung lebih hangat. Kenaikan suhu 4-6 ${ }^{\circ} \mathrm{C}$ dapat menimbulkan kerusakan suatu komunitas. Kisaran suhu yang optimal bagi kehidupan Drupella berkisar 28-30 ${ }^{\circ} \mathrm{C}$ (MOYER ET AL. 1982).

pH dan kadar Dissolved Oxygen juga dapat mempengaruhi keberadaan Drupella pada suatu perairan. Nilai pH yang diperoleh pada stasiun pengamatan berkisar antara 7,1-7,3 pada daerah rataan karang maupun daerah tubir. Nilai Dissolved Oxygen yang didapatkan pada stasiun pengamatan berkisar antara 4-4,7 pada daerah rataan karang maupun daerah tubir. Kedua parameter tersebut tentunya memiliki pengaruh terhadap keberadaan Drupella dan kelangsungan hidup terumbu karang.

Total Suspended Solid berkorelasi positif dengan terumbu karang dengan nilai berkisar antara 0,12-0,20 pada daerah rataan karang maupun daerah tubir. Semakin tinggi nilai Total Suspended Solid maka semakin berpengaruh pula terhadap keberadaan terumbu karang dan Drupella pada perairan dikarenakan tingkat kekeruhan yang dihasilkan akan berpengaruh bagi 
kehidupan karang di perairan yang akan berpengaruh terhadap keberadaan Drupella.

Grafik Principal Component Analysis (PCA) yang menunjukkan hubungan kepadatan Drupella dengan dan parameter lingkungan terlihat pada Gambar 6 (a). Hasil analisis menunjukkan bahwa kualitas informasi disajikan oleh kedua sumbu (F1 dan F2), total kepadatan Drupella pada setiap stasiun daerah tubir dapat dijelaskan melalui dua sumbu utama tersebut sebesar $83,93 \%$.

Hubungan kepadatan Drupella dan parameter perairan menunjukkan bahwa Drupella berkorelasi positif dengan parameter suhu, arus, pH, Dissolved Oxygen, dan Total Suspended Solid. Korelasi tersebut menunjukkan adanya hubungan erat antara kepadatan Drupella dengan beberapa parameter perairan dikarenakan parameter tersebut memiliki pengaruh terhadap keberadaan Drupella.

Suhu perairan merupakan faktor yang dapat mempengaruhi keberadaan Drupella. Pada stasiun pengamatan daerah tubir memiliki rata-rata suhu sebesar 29-31 ${ }^{\circ} \mathrm{C}$. Suhu pada daerah tubir lebih rendah dibandingkan dengan daerah rataan karang dikarenakan adanya perbedaan intensitas cahaya yang masuk kedalam perairan dan juga perbedaan kedalaman perairan. Pada daerah tubir memiliki kedalaman 5-11 meter sehingga intensitas cahaya yang masuk akan cenderung lebih sedikit dibandingkan daerah rataan karang sehingga kondisi perairan cenderung lebih dingin. Drupella dapat hidup dan berkembang biak dengan baik dengan kisaran suhu $28-31{ }^{\circ} \mathrm{C}$ (LALANG ET AL. 2013).

$\mathrm{pH}$ dan kadar Dissolved Oxygen juga dapat mempengaruhi keberadaan Drupella pada suatu perairan. Nilai $\mathrm{pH}$ yang diperoleh pada stasiun pengamatan berkisar antara 7,1-7,3 sama dengan daerah rataan karang. Nilai Dissolved Oxygen yang didapatkan pada stasiun pengamatan berkisar antara 4-4,7. Kedua parameter tersebut tentunya memiliki pengaruh terhadap keberadaan Drupella dan kelangsungan hidup terumbu karang.

Total Suspended Solid berkorelasi positif dengan terumbu karang yang ada di Pulau Semujur dengan nilai berkisar antara 0,12-0,20 pada daerah rataan karang maupun daerah tubir. Nilai tersebut termasuk lebih tinggi dibandingkan pada daerah tubir. Semakin tinggi nilai Total Suspended Solid maka semakin berpengaruh pula terhadap keberadaan terumbu karang dan Drupella pada perairan dikarenakan tingkat kekeruhan yang dihasilkan akan berpengaruh bagi kehidupan karang maupun keberadaan Drupella di perairan.

Hubungan Kepadatan Drupella dengan Terumbu Karang pada daerah rataan karang dan daerah tubir

Hasil Correspondence Analysis (CA) menunjukkan bahwa hubungan Drupella pada 5 stasiun pengamatan daerah rataan karang terpusat pada sumbu utama (F1 dan F2) dengan total sebesar 86,95\%. (F1 = 58,71\% dan F2 = $28,24 \%$ ). Tabel principal coordinates disajikan pada Lampiran 5.
Drupella yang ditemukan pada daerah terumbu karang menunjukkan adanya korelasi positif antara kepadatan Drupella dengan bentuk pertumbuhan karang acropora submassive, acropora tabulate, coral submassive, dan coral massive. Korelasi tersebut menunjukkan adanya hubungan antara kepadatan Drupella dengan beberapa bentuk pertumbuhan karang. Pada daerah rataan karang ditemukan beberapa karang yang mati akibat dari pemangsaan Drupella. Karang dengan jenis lifeform jenis Acropora merupakan habitat yang paling disukai oleh Drupella dengan memanfaatkan karang dengan bentuk pertumbuhan tersebut sebagai tempat hidup dan berlindung serta sebagai sumber makanannya dengan cara memangsa polip karang tersebut. Drupella juga bergantung dan membutuhkan bentuk pertumbuhan karang bercabang sebagai tempat berlindung dan berkembang biak serta sebagai substrat untuk menempelkan telurnya. Drupella akan cenderung lebih memilih bentuk pertumbuhan karang bercabang karenn ketersediaan makanan yang lebih banyak. Kondisi karang seperti aksesibilitas jaringan, nilai gizi, produksi lendir, dan pertahan sel penyegat karang sangat menentukan posisi Drupella pada cabang karang (MORTON AND BLACKMORE, 2009). Kelimpahan dan ketersediaan makanan pada bentuk pertumbuhan karang yang bercabang juga menentukan keberadaan Drupella karena cenderung memiliki ketersediaan polip yang lebih banyak (TURNER, 1994). Daerah rataan karang didominasi oleh jenis lifeform Acropora. Drupella juga lebih banyak ditemukan pada daerah karang yang rusak agar terhindar dari sel penyengat karang. Drupella tidak menyerang jaringan karang sehat karena karang yang sehat memiliki sel penyengat (MORTON ET AL. 2002). Drupella memilih bentuk pertumbuhan koloni karang, kemudahan mengambil jaringan karang yang hidup, produksi lendir dari karang, nilai nutrisi jaringan karang, dan kemampuan pertahanan sel penyengat karang (GABBI, 1999). Drupella yang ditemukan pada daerah rataan karang lebih banyak dibandingkan pada daerah tubir.

Hasil Correspondence Analysis (CA) menunjukkan bahwa hubungan Drupella pada 5 stasiun pengamatan daerah tubir terpusat pada sumbu utama (F1 dan F2) yang memberikan kontribusi terhadap keragaman total sebesar $73,74 \%(\mathrm{~F} 1=49,86 \%, \mathrm{~F} 2=23,88 \%)$.

Drupella yang ditemukan pada daerah terumbu karang menunjukkan adanya korelasi positif antara kepadatan Drupella dengan bentuk pertumbuhan karang berupa acropora digitate, acropora submassive, acropora tabulate, coral submassive, dan coral branching. Drupella yang ditemukan pada daerah ini lebih sedikit dibandingkan pada daerah rataan karang dikarenakan jenis lifeform lebih banyak didominasi oleh coral massive dan kondisi karang yang masih cukup baik sehingga Drupella kurang menyukai daerah tersebut. Kurangnya sumber makanan berupa polip karang juga mempengaruhi keberadaan hewan tersebut. Kebanyakan individu Drupella rugosa cenderung lebih menyukai daerah karang dengan bentuk pertumbuhan bercabang seperti Acropora (MORTON AND BLACKMORE, 2009). 
Kurangnya ketersediaan karang bercabang akan mempengaruhi jumlah individu Drupella yang hidup pada ekosistem terumbu karang (MCCLANAHAN, 1997).

Berdasarkan hasil penelitian dapat dilihat bahwa populasi Drupella pada ekosistem terumbu karang di perairan Pulau Semujur belum memberikan ancaman yang besar terhadap ekosistem terumbu karang. Efek dan kerusakan yang ditimbulkan oleh Drupella saat ini masih dalam skala kecil dan belum termasuk wabah yang tumbuh secara pesat.

\section{SIMPULAN DAN SARAN \\ Simpulan}

Terdapat 2 spesies Drupella yang ditemukan di perairan Pulau Semujur yaitu Drupella rugosa dan Drupella cornus. Kepadatan rata-rata pada daerah rataan karang sebanyak 4.880 ind/ha. sedangkan kepadatan ratarata pada daerah tubir sebanyak 620 ind/ha. Persentase tutupan karang tertinggi daerah rataan karang sebesar $72,20 \%$ kategori baik dan terendah 23,44\% kategori rusak. Persentase tutupan karang tertinggi pada daerah pada daerah tubir sebesar 54,96\% kategori baik dan terendah 29,14\% kategori sedang. Principal Component Analysis (PCA) daerah rataan karang dan tubir Drupella berkorelasi positif dengan parameter arus, suhu, $\mathrm{pH}$, Dissolved Oxygen, dan Total Suspended Solid. Correspondence Analysis (CA) daerah rataan karang berkorelasi positif dengan jenis lifeform acropora dan coral massive dengan kategori persentase tutupan karang rusak sedangkan daerah tubir Drupella berkorelasi positif dengan jenis lifeform acropora, coral submassive dan coral branching dengan kategori persentase tutupan karang sedang.

\section{Saran}

Penelitian ini sebaiknya dilakukan agar lebih mempertimbangkan waktu dan perkiraan cuaca supaya mendukung dalam melakukan pengambilan data. Hasil dari penelitian ini sebaiknya dimanfaatkan sebagai data dasar untuk menyusun strategi pengelolaan sumberdaya dan pembentukan kebijakan untuk perlindungan kelestarian ekosistem terumbu karang. Perlu adanya penelitian lanjutan mengenai kehadiran yang berada di daerah terumbu karang, kepadatan spesies maupun individu Drupella dan cara mengendalikannya, ekosistem dan kondisi lingkungan yang berbeda, serta rencana pemanfaatan sumberdaya secara berkelanjutan tanpa mengeksploitasi ketersediannya di alam.

\section{UCAPAN TERIMAKASIH}

Pada kesempatan ini penilis mengucapkan terimakasih yang sebesar-besarnya kepada Ayahanda Usman dan Ibunda Ratna Dewi, serta Suami Ahmad Robuan dan adik serta kakak atas do'a, dukungan, kasih saying, dan materil yang tar trhingga yang diberikan kepada penulis hingga dapat menyelesaikan kuliah dan skripsi ini. Dosen-dosen beserta staf Manajemen Sumberdaya Perairan dan temanteman seangkatan yang membantu dalam proses penyusunan prosposaal hinggi slesai skripsi ini.

\section{DAFTAR PUSTAKA}

Arbi UY. 2009. Gastropoda dan Pelecypoda di Perairan Pelabuhan Gresik Jawa Timur. Berkala Ilmiah Biologi 8(1):1-8.

Bengen DG. 2000. Teknik Pengambilan Contoh dan Analisis Data Biofisik Sumberdaya Pesisir. Bogor: Pusat Kajian Sumberdaya Pesisir dan Lautan, Fakultas Perikanan dan Ilmu Kelautan, Institut Pertanian Bogor.

Brower JE, Zar JH and Von Ende CN. 1998. Field and labolatory methods for general ecology. The McGraw-Hill Companies. USA.

Cumming RL. 1996. The Corallivorous Gastropods D. cornus, D. fragum and D. rugosa: Ecology And Impact on Coral Communities at Lizard lsland. Great Barrier Reef. [Thesis]. James Cook University of North Queensland: Townsville. Australia.

Cumming RL. 1997. High Densities of Coral Feeding Gastropods Thresthen Hongkong's Coral Communities. Newsletter of the Department of Ecology and Biodiversity. Hongkong University: 4-5.

Cumming RL. 1999. Multiscale Variation in The Density of Three Corallivorous Gastropods Drupella sp. Coral Reefs. Predation on Reef-Building Corals 1(8):147-157.

Dinas Kelautan dan Perikanan Bangka Tengah. 2007. Gambaran Umum Pulau Semujur.

English S, Wilkinson C and Baker V. 1994. Survey Manual for Tropical Marine Resources. Townsville: Australian Institute of Marine Science.

Fachrul MF. 2007. Metode Sampling Bioekologi. Jakarta: PT.Bumi Aksara.

Gabbi, G. 1999. Guide to the Jewels of the Sea. Shells. Periplus. Turin.

Hill J and Wilkinson C. 2004. Methods for Ecological Monitoring of Coral Reefs (Version 1). Townsville: Australia Institute of Marine Science.

Keputusan Menteri Lingkungan Hidup No. 51 Tahun 2004. Baku Mutu Air Laut.

Keputusan Menteri Lingkungan Hidup No.4 Tahun 2001. Kriteria Baku Kerusakan Terumbu Karang.

Lalang, Baru Sadarun, La Ode Muh Yasir Haya. 2013. Kelimpahan Drupella dan Kondisi Terumbu Karang di Perairan Pulau Mandike Selat Tiworo Kabupaten Muna, Sulawesi Tenggara. Jurnal Mina Laut Indonesia 1(1):12-22.

Latuconsina H. 2016. Ekologi Perairan Tropis : Prinsip Dasar Pengelolaan Sumber Daya Hayati Perairan. Yogyakarta: Gadjah Mada University Press. 
Mc Clanahan TR. 1997. Dynamics of Drupella Cornus populations on Kenyan Coral Reefs. The wildlife Conservation society, Coral Reef Conservation project, P.O. Box 99470, Mombasa, Kenya.

Morton B, Blackmore G and Kwok CT. 2002. Corallivory abd prey choice by Drupella rugosa (Gastropoda:Muricidae) in Hongkong. Molluscan Studi (1)8:217-223.

Morton B and Blackmore G. 2009. Seasonal Variations In The Density Of And Corallivory by Drupella rugosa and Species Cronia margariticola (Caenogastropoda: Muricidae) from the Coastal Waters of HongKong. J Mar Biol Assoc UK 8(9):147-159.

Moyer JT, Emerson WK and Ross M. 1982. Massive Destructian of Scleractinian Corals by the Muricid Gastropod, Drupella, in Japan and the Philippines. Nautilus (1)6:69-82.

Muzaki FK, Muhajir F, Ariyanto G, Rimayanti R. dan Siringoringo RM. 2010. Kondisi Terumbu Karang di Perairan Kabupaten Bangka Barat, Bangka Tengah dan Bangka Selatan, Provinsi Bangka Belitung. Di dalam : Direktorat Kelembagaan, Direktorat, Jendral Pendidikan Tinggi, Kementerian Pendidikan Nasional dan LIPI. Perairan Propinsi Kepulauan Bangka-Belitung: Sumberdaya Hayati Laut dan Oseanografi. Jakarta: LIPI Press 1(2):16-25.

Riska, Baru Sadarun, La Ode Muh Yasir Haya. 2013. Kelimpahan Drupella dan Kondisi Terumbu Karang di Perairan Pulau Mandike Selat Tiworo Kabupaten Muna, Sulawesi Tenggara. Jurnal Mina Laut Indonesia 1(1):12-22.

Riska, Baru Sadarun, La Ode Muh Yasir Haya. 2013. Kelimpahan Drupella Pada Perairan Terumbu Karang di Pulau Belan-Belan Besar Selat Tiworo Kabupaten Muna, Sulawesi Tenggara. Jurnal Mina Laut Indonesia 2(6):69-80.

Nurhayati S, Irawan H dan Pratomo A. 2016. Hubungan Kelimpahan Drupella sp Terhadap Kondisi Tutupan Terumbu Karang Di Perairan Pulau Pucung Desa Malang Rapat Kecamatan Gunung Kijang. FIKP UMRAH.

Suharsono. 2008. Jenis-jenis Karang di Indonesia. Jakarta: LIPI Press. Supriharyono. 2000. Pengelolaan Ekosistem Terumbu Karang. Djambatan. Jakarta .129 hlm.

Turner SJ, 1994. The biology and Population Outbreaks of the Corallivorous Gastropod Drupella on IndoPacific reefs. Oceanography and Marine Biology: an Annual Review 32:461-530.

Veron JEN. 2000. Corals of The World. Townsville: Australian Institute of Marine Science. 